\title{
Analisis Pembiayaan Murabahah Berdasarkan Psak 102 Syariah Pada PT Bank Sumsel Babel Syariah Cabang Lubuklinggau
}

\author{
Yayuk Marliza', Firdaus ${ }^{2}$ \\ 1 Universitas Musi Rawas Lubuk Linggau, marlizayayuk77@gmail.com \\ 2Universitas Musi Rawas Lubuk Linggau, ajafirdaus154@gmail.com
}

\begin{abstract}
The aim of this study is to see the accounting treatment toward Murabahah Financing Based on PSAK102 Syariah in PT Bank Sumsel Babel Syariah Lubuklinggau. The research method us in reasearch in apllying objectives, the data used are primary data and secondary data. Data collection techniques used is obeservation, interviews and documentations. Technique of analiysis is qualitative analysis technique. The results of the analysis showed that there were significant differences in accounting treatment based on PSAK 102 Syariah. in PSAK 102 it has regulated about recognition and measurrement of down payment while the Bank was disclosing it because the existence of business policies seen necessary in accordance the the situation in the Bank.
\end{abstract}

Keyword: Murabahah based on PSAK 102 Syariah

\begin{abstract}
ABSTRAK
Rumusan masalah yang akan diteliti oleh penulis yaitu Bagaimana Pembiayaan Murabahah Berdasarkan PSAK 102 Syariah Pada PT Bank Sumsel Babel Syariah Cabang Lubuklinggau. Tujuannya adalah untuk mengetahui Perlakuan Akuntansi Atas Pembiayaan Murabahah Berdasarkan PSAK 102 Syariah Pada PT. Bank Sumsel Babel Syariah Cabang Lubuklinggau. Metode penelitian yang digunakan dalam penelitian adalah kualitatif deskriptip. Data yang digunakan adalah data primer dan data sekunder. Teknik pengumpulan data yang digunakan adalah observasi, wawancara dan dokumentasi. Tehknik Analisis data yang digunakan adalah teknik analisis kualitatif. Hasil analisis menunjukan terdapat perbedaan antara perlakuan akuntansi yang diterapkan Pada PT. Bank Sumsel Babel Syariah Cabang Lubuklinggau dengan perlakuan akuntansi yang berdasarkan PSAK 102 Syariah. Perbedaan yang dimaksud ialah adanya perlakuan akuntansi yang diatur didalam PSAK 102 tidak diberlakukan pada PT. Bank Sumsel Babel Syariah Cabang Lubuklinggau. Didalam PSAK 102 diatur tentang pengakuan dan pengukuran uang muka sedangkan pada PT. Bank Sumsel Babel Syariah Cabang Lubuklinggau tidak diungkapkan. Hal ini dikarenakan oleh adanya kebijakan bisnis yang dianggap perlu disesuaikan dengan situasi di perusahaan.
\end{abstract}

Kata Kunci : Murabahah berdasarkan PSAK 102 Syariah.

\section{A. PENDAHULUAN}

Berdasarkan Undang-Undang Syariah Indonesia Nomor. 21 Tahun 2008, disebutkan bahwa Bank terdiri atas dua jenis, yaitu Bank Konvensional dan Bank Syariah. Bank konvensional adalah bank yang menjalankan kegiatan usahanya secara konvensional yang terdiri atas Bank Umum Konvensional dan Bank Perkreditan Rakyat. Adapun Bank Syariah adalah bank yang menjalankan kegiatan usahanya berdasarkan prinsip syariah yang terdiri atas Bank Umum Syariah, Bank Pembiayaan Rakyat Syariah (Rizal Yaya, dkk, 2012: 22).

Sistem perbankan syariah berbeda dengan sistem perbankan konvensional, karena sistem keuangan dan perbankan syariah merupakan sub sistem dari suatu sistem ekonomi islam yang cakupanya lebih luas. Karena itu, perbankan syariah tidak hanya dituntut untuk menghasilkan profit secara komersial, namun dituntut 
secara sungguh-sungguh menampilkan nilai-nilai syariah. Tujuan dari pendirian bank-bank islam/syariah ini umumnya adalah untuk mempromosikan dan mengembangkan aplikasi dari prinsip-prinsip islam, syariah dan tradisinya kedalam transaksi keuangan dan perbankan serta bisnis lain yang terkait agar umat terhindar dari hal-hal yang dilarang. Meskipun sesungguhnya islam bukanlah satu-satunya agama yang melarang pembayaran bunga, tapi semua agama yang ada didunia ini melarang penerapan bunga (Ikit dan Muhammad Saleh, 2014: 83).

Bagi industri perbankan syariah, pelarangan transaksi yang haram zatnya tersebut diwujudkan dalam bentuk larangan memberikan pembiayaan yang terkait dengan aktivitas pengadaan jasa, produksi makanan, minuman, dan bahan konsumsi lain yang diharamkan oleh Majelis Ulama Indonesia (MUI). Dalam pemberian pembiayaan, bank syariah dituntut untuk selalu memastikan kehalalan jenis usaha yang dibantu pembiayaannya oleh bank syariah. dengan demikian, pada suatu bank syariah tidak akan ditemui adanya pembiayaan untuk usaha yang bergerak dibidang peternakan babi, minuman keras, ataupun jenis pornografi dan lainya yang diharamkan (Rizal Yaya, dkk,2012: 39).

Ada dua jenis pembiayaan pada PT. Bank Sumsel Babel Syariah Cabang Kota Lubuklinggau, yaitu Pembiayaan Konsumtif dan Pembiayaan Produktif yang diatur didalam berbagai macam akad, diantaranya akad Murabahah. Murabahah berdasarkan PSAK 102 (paragraf 5) adalah menjual barang dengan harga jual sebesar harga perolehan ditambah keuntungan yang disepakati dan penjual harus mengungkapkan harga perolehan barang tersebut kepada pembeli. Biaya perolehan adalah jumlah kas atau setara dengan kas yang dibayarkan untuk memperoleh suatu aset sampai dengan aset tersebut dalam kondisi dan tempat yang siap dijual atau digunakan. Pembayaran Murabahah dapat dilakukkan secara tunai atau tangguh. Pembayaran tangguh adalah yang dilakukan tidak pada saat barang diserahkan kepada pembeli, tetapi pembayaran dilakukan secara angsuran atau sekaligus pada waktu tertentu. Landasan hukum dalam akad Murabahah dapat kita lihat dalam Qur'an Surah Al-Baqarah ayat :2 : 280. Yang artinya "Dan jika (orang yang berhutang itu) dalam kesukaran, maka berilah tangguh sampai dia berkelapangan. Menyedekahkan ( sebagian/semua hutang) itu, lebih baik bagimu, jika kamu mengetahui (Ikit dan Muhammad Saleh, 2014: 145).

Adapun yang menjadi obyek penelitian oleh penulis adalah PT. Bank Sumsel Babel Syariah Cabang Lubuklinggau. Perusahaan ini merupakan perusahaan yang bergerak dibidang jasa, yaitu umumnya menghimpun dan menyalurkan dana.

Pembiayaan dengan akad murabahah pada PT. Bank Sumsel Babel Syariah Cabang Lubuklinggau itu sendiri terdapat di didalam pembiayaan Konsumtif yang memang sifatnya mengatur tentang kegiatan jual beli didalam perbankan Syariah.

Produk pembiayaan murabahah dapat dilakukan secara angsuran ataupun ditangguhkan dengan kesepakatan bersama. Dalam prakteknya kontrak murabahah yang dilakukan pada Bank Sumsel Babel Syariah Cabang Lubuklinggau adalah dengan menggunakan sistem murabahah dengan pesanan. Kondisi ini dapat dimaklumi mengingat Bank Sumsel Babel Syariah Cabang Lubuklinggau bukanlah sebagai tempat yang menyediakan suatu barang atau komoditas tertentu yang dibutuhkan oleh seorang nasabah. Untuk mengadakan barang atau komoditas yang dibutuhkan nasabah, pihak PT. Bank Sumsel Babel Syariah Cabang Lubuklinggau terlebih dahulu melakukan pemesanan kepada pemasok (pihak ketiga) yang kemudian disalurkan kepada nasabah yang memesannya. Adanya kebijakan bisni yang dianggap perlu dilakukan oleh pihak PT. Bank Sumsel Babel Syariah Cabang 
Lubuklinggau. Dalam kebijakanya PT. Bank Sumsel Babel Syariah Cabang Kota Lubuklinggau tidak memberlakukan adanya Uang Muka dari nasabahnya, PT. Bank Sumsel Babel Syariah Cabang Lubuklinggau juga tidak mencatat adanya Beban Murabahah Tangguhan. Dari Transaksi pembiayaan murabahah tersebut maka dibutuhkan kerangka akuntansi yang mengatur secara menyeluruh atas kegiatan transaksi Pembiayaan Murabahah tersebut, sehingga dapat menghasilkan pengakuan, pengukuran, penyajian dan pengungkapan akuntansi yang tepat dan sesuai yang telah diatur didalam PSAK 102 sehingga dapat mengkomunikasikan informasi akuntansi secara tepat waktu dan kualitas yang dapat diandalkan. Berdasarkan uraian tersebut, peneliti akan melakukan analisis pembiayaan Murabahah pada PT. Bank Sumsel Babel Syariah Cabang Lubuklinggau.

Berdasarkan latar belakang yang telah diuraikan di atas, maka dapat dirumuskan masalah yaitu : Bagaimana Pembiayaan Murabahah Berdasarkan PSAK 102 Syariah Pada PT Bank Sumsel Babel Syariah Cabang Lubuklinggau.

Penelitian ini bertujuan untuk mengetahui Pembiayaan Murabahah Berdasarkan PSAK 102 Syariah Pada PT Bank Sumsel Babel Syariah Cabang Lubuklinggau.

\section{B. KAJIAN TEORI}

Menurut PSAK 102, Murabahah adalah akad jual beli barang dengan harga jual sebesar biaya perolehan ditambah dengan keuntungan yang disepakati oleh kedua belah pihak dan penjual harus mengungkapkan biaya perolehan barang tersebut kepada pembeli.

Murabahah adalah akad jual beli barang dengan menjelaskan kepada pembeli mengenai harga perolehan barang dan ditambah dengan keuntungan (margin) yang disepakati oleh kedua belah pihak (Ikit, 2014:145).

Jual beli sebagai sebuah perbuatan hukum yang mempunyai konsekuensi terjadinya peralihan hak atas sesuatu barang dari pihak penjual kepada pihak pembeli mempunyai landasan hukum yang dapat kita jumpai dalam Al-Qur'an, yaitu sebagai berikut:

a. Al-Qur'an surat An-Nisa [4]:29

Dalam hukum jual beli dapat kita jumpai dalam surat An-Nisa [4]:29

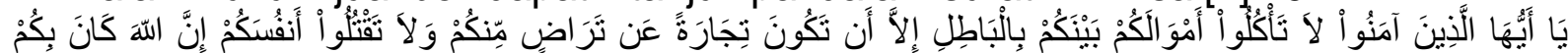

Yang artinya "Hai orang-orang yang beriman, janganlah kamu saling memakan harta sesamamu dengan jalan yang batil, kecuali dengan jalan perniagaan (jual-beli) yang berlaku dengan suka sama suka diantara kamu".

b. surat Al-baqarah [2] : 257

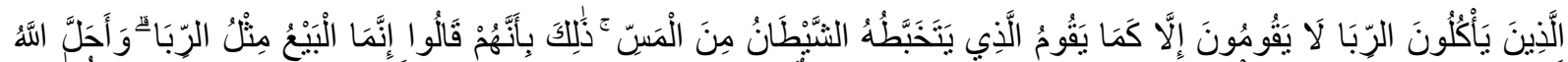

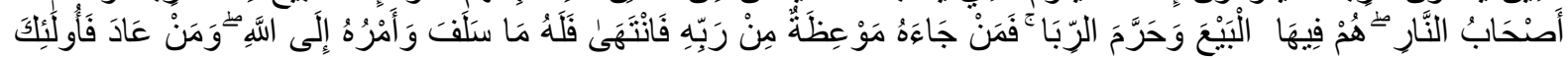
خَالِذُون

Artinya: Orang-orang yang makan (mengambil) riba tidak dapat berdiri melainkan seperti berdirinya orang yang kemasukan syaitan lantaran (tekanan) penyakit gila. Keadaan mereka yang demikian itu, adalah disebabkan mereka berkata (berpendapat), sesungguhnya jual beli itu sama dengan riba, padahal Allah telah menghalalkan jual beli dan mengharamkan riba. Orang-orang yang telah sampai kepadanya larangan dari Tuhannya, lalu terus berhenti (dari mengambil riba), maka 
baginya apa yang telah diambilnya dahulu (sebelum datang larangan); dan urusannya (terserah) kepada Allah. Orang yang kembali (mengambil riba), maka orang itu adalah penghuni-penghuni neraka; mereka kekal di dalamnya. (Umam Khotibul dan Utomo Setiawan, 2016:104).

Objek akad transaksi dalam pembiayaan Rukun Murabahah meliputi barang dan harga barang yang diperjualbelikan:

a. Barang

Terkait dengan barang, fatwa Dewan Syariah Nasional (DSN) No. 4 menyatakan bahwa jual beli Murabahah, barang yang diperjualbelikan bukanlah barang yang diharamkan oleh syariah islam. DSn mensyaratkan bank membeli barang yang diperlukan nasabah atas nama bank sendiri dan harus menyampaikan semua hal yang berkaitan dengan pembelian kepada nasabah, misalnya jika pembelian dilakukan secara utang.

b. Harga barang

Bank menjual barang dengan harga jual senilai harga beli plus keuntunganya. Dalam hal ini fatwa DSN Nomor 4 mensyaratkan bank memberitahu secara jujur harga pokok barang kepada nasabah, berikut biaya yang diperlukan. Selanjutnya nasabah membayar harga barang tersebut berdasarkan jangka waktu dan metode pembayaran yang telah disepakati (Rizal Yaya, dkk, 2012: 181).

Menurut Ikit (2014 : 153) ada bebrapa rukun akad murabahah yang harus dipenuhi dalam transaksi yaitu:

a. Adanya pelaku yaitu pembeli yang sempurna (cakap hukum, baligh) dan adanya penjual (pihak yang memproduksi barang dengan pesanan).

b. Adanya objek akad murabahah yaitu jenis, kuantitas, kualitasnya, halal, manfaatnya dan harga barang harus diketahui dengan jelas dan benar sehingga terhindar dari hal-hal yang merusak akad murabahah. Adanya serah terima (ijab dan qabul) artinya adanya pernyataan dari kedua belah pihak untuk saling rela dalam serah terima barang.

Murabahah dibagi menjadi 2 jenis yaitu :

a. Murabahah berdasarkan pesanan

Murabahah berdasarkan pesanan adalah Bank syariah akan melakukan pembelian barang setelah ada pesanan dari Nasabah atau pembeli. Artinya Murabahah ini bersifat mengikat, pembeli harus membeli barang yang dipesannya dan tidak dapat membatalkan pesananya.

b. Murabahah tanpa pesanan.

Murabahah tanpa pesanan adalah Murabahah dilakukan tanpa melihat ada atau tidaknya pesanan sehingga persediaan dilakukan sendiri. Pembayaran Murabahah dapat dilakukan secara tunai atau tangguh. Pembayaran tangguh adalah pembayaran yang dilakukan tidak pada saat barang diserahkan kepada pembeli, tetapi pembayaran dilakukan secara angsuran atau sekaligus pada waktu tertentu.

Jual beli Murabahah mengacu Standar akuntansi pada PSAK 102 tentang Murabahah yang mulai berlaku secara efektif per tanggal 1 Januari 2008. PSAK 102 menggantikan PSAK 59 yang menyangkut tentang pengakuan, pengukuran, penyajian dan pengungkapan Murabahah. PSAK 102 juga dapat diterapkan oleh 
pihak-pihak yang yang melakukan transaksi Murabahah dengan Lembaga Keuangan Syariah atau Kopeasi Syariah. Lembaga Keuangan Syariah yang dimaksud dalam PSAK 102 tersebut, meliputi: Perbankan Syariah, Lembaga Keuangan Syariah nonbank ( Asuransi, Lembaga pembiayaan dan Dana pensiun), dan Lembaga Keuangan lainya yang diizinkan oleh peraturan perundang-undangan yang berlaku untuk menjalankan transaksi Murabahah (Kautsar Rizal Salman, 2017:229).

Berikut tentang pengakuan, pengukuran, penyajian dan pengungkapan murabahah berdasarkan PSAK 102.

a. Pengakuan dan pengukuran

Adapun Pengakuan dan pengukuran atas transaksi akad Murabahah berdasarkan PSAK 102 sebagai berikut.

PSAK 102 Paragraf 18

Pada saat perolehan, aset murabahah diakui sebagai persediaan sebesar biaya perolehan.

\section{PSAK 102 Paragraf 19}

Pengukuran aset murabahah setelah perolehan adalah sebagai berikut:

a) Jika murabahah pesanan mengikat, maka:

$>$ Dinilai sebesar biaya perolehan; dan

$>$ Jika terjadi penurunan nilai aset karena usang, rusak, atau kondisi lainnya sebelum diserahkan ke nasabah, penurunan nilai tersebut diakui sebagai beban dan mengurangi nilai aset:

b) Jika murabahah tanpa pesanan, maka:

$>$ Dinilai berdasarkan biaya perolehan atau nilai neto yang dapat direalisasi, mana yang lebih rendah; dan

$>$ Jika nilai neto yang dapat direalisasi lebih rendah dari biaya perolehan, maka selisihnya diakui sebagai kerugian.

PSAK 102 Paragraf 20

Diskon pembelian aset murabahah diakui sebagai:

a) Pengurang biaya perolehan aset murabahah, jika terjadi sebelum akad murabahah

b) Liabilitas kepada pembeli, jika terjadi setelah akad murabahah dan sesuai akad yang disepakati menjadi hak pembeli;

c) Tambahan keuntungan murabahah, jika terjadi setelah akad murabahah dan sesuai akad menjadi hak penjual; atau

d) Pendapatan operasi lain, jika terjadi setelah akad murabahah dan tidak diperjanjikan dalam akad.

PSAK 102 Paragraf 21

Liabilitas penjual kepada pembeli atas pengembalian diskon pembelian akan tereliminasi pada saat:

a) Dilakukan pembayaran kepada pembeli sebesar jumlah potongan setelah dikurangi dengan biaya pengembalian; atau

b) Dipindahkan sebagai dana kebajikan jika pembeli sudah tidak dapat dijangkau oleh penjual.

PSAK 102 Paragraf 22

Pada saat akad murabahah, piutang murabahah diakui sebesar biaya perolehan aset murabahah ditambah keuntungan yang disepakati. Pada akhir periode laporan keuangan, piutang murabahah dinilai sebesar nilai neto yang dapat direalisasi, yaitu saldo piutang dikurangi penyisihan kerugian piutang.

PSAK 102 Paragraf 23 
Keuntungan murabahah diakui:

a) Pada saat terjadinya penyerahan barang jika dilakukan secara tunai atau secara tangguh yang tidak melebihi satu tahun; atau

b) Selama periode akad sesuai dengan tingkat risiko dan upaya untuk merealisasikan keuntungan tersebut untuk transaksi tangguh lebih dari satu tahun. Metode-metode berikut ini digunakan, dan dipilih yang paling sesuai dengan karakteristik risiko dan upaya transaksi murabahah-nya:

$>$ Keuntungan diakui saat penyerahan aset murabahah. Metode ini terapan untuk murabahah tangguh di mana risiko penagihan kas dari piutang murabahah dan beban pengelolaan piutang serta penagihannya relatif kecil.

$>$ Keuntungan diakui proporsional dengan besaran kas yang berhasil ditagih dari piutang murabahah. Metode ini terapan untuk transaksi murabahah tangguh di mana risiko piutang tidak tertagih relatif besar dan/atau beban untuk mengelola dan menagih piutang tersebut relatif besar juga.

> Keuntungan diakui saat seluruh piutang murabahah berhasil ditagih. Metode ini terapan untuk transaksi murabahah tangguh di mana risiko piutang tidak tertagih dan beban pengelolaan piutang serta penagihannya cukup besar. Dalam praktik, metode ini jarang dipakai, karena transaksi murabahah tangguh mungkin tidak terjadi bila tidak ada kepastian yang memadai akan penagihan kasnya.

\section{PSAK 102 Paragraf 24}

Pengakuan keuntungan, dalam paragraf 23 (b) (ii), dilakukan secara proporsional atas jumlah piutang yang berhasil ditagih dengan mengalikan persentase keuntungan terhadap jumlah piutang yang berhasil ditagih. Persentase keuntungan dihitung dengan perbandingan antara marjin dan biaya perolehan aset murabahah.

* PSAK 102 Paragraf 25

Berikut ini contoh perhitungan keuntungan secara proporsional untuk suatu transaksi murabahah dengan biaya perolehan aset (pokok) Rp 800 dan keuntungan Rp 200; serta pembayaran dilakukan secara angsuran selama tiga tahun; dimana jumlah angsuran, pokok, dan keuntungan yang diakui setiap tahun adalah sebagai berikut:

\section{PSAK 102 Paragraf 26}

Potongan pelunasan piutang murabahah yang diberikan kepada pembeli yang melunasi secara tepat waktu atau lebih cepat dari waktu yang disepakati diakui sebagai pengurang keuntungan murabahah.

* PSAK 102 Paragraf 27

Pemberian potongan pelunasan piutang murabahah dapat dilakukan dengan menggunakan salah satu metode berikut:

a). Diberikan pada saat pelunasan, yaitu penjual mengurangi piutang murabahah dan keuntungan murabahah; atau

b). Diberikan setelah pelunasan, yaitu penjual menerima pelunasan piutang dari pembeli dan kemudian membayarkan potongan pelunasannya kepada pembeli.

PSAK 102 Paragraf 28

Potongan angsuran murabahah diakui sebagai berikut: 
a) Jika disebabkan oleh pembeli yang membayar secara tepat waktu, maka diakui sebagai pengurang keuntungan murabahah;

b) Jika disebabkan oleh penurunan kemampuan pembayaran pembeli, maka diakui sebagai beban.

\section{PSAK 102 Paragraf 29}

Denda dikenakan jika pembeli lalai dalam melakukan kewajibannya sesuai dengan akad, dan denda yang diterima diakui sebagai bagian dana kebajikan.

* PSAK 102 Paragraf 30

Pengakuan dan pengukuran uang muka adalah sebagai berikut:

> Uang muka diakui sebagai uang muka pembelian sebesar jumlah yang diterima;

> Jika barang jadi dibeli oleh pembeli, maka uang muka diakui sebagai pembayaran piutang (merupakan bagian pokok);

> Jika barang batal dibeli oleh pembeli, maka uang muka dikembalikan kepada pembeli setelah diperhitungkan dengan biaya-biaya yang telah dikeluarkan oleh penjual.

\section{PSAK 102 Paragraf 31}

Utang yang timbul dari transaksi murabahah tangguh diakui sebagai utang murabahah sebesar harga beli yang disepakati (jumlah yang wajib dibayarkan).

\section{PSAK 102 Paragraf 32}

Aset yang diperoleh melalui transaksi murabahah diakui sebesar biaya perolehan murabahah tunai. Selisih antara harga beli yang disepakati dengan biaya perolehan tunai diakui sebagai beban murabahah tangguhan.

* PSAK 102 Paragraf 33

Beban murabahah tangguhan diamortisasi secara proporsional dengan porsi utang murabahah.

* PSAK 102 Paragraf 34

Diskon pembelian yang diterima setelah akad murabahah, potongan pelunasan, dan potongan utang murabahah diakui sebagai pengurang beban murabahah tangguhan.

\section{PSAK 102 Paragraf 35}

Denda yang dikenakan akibat kelalaian dalam melakukan kewajiban sesuai dengan akad diakui sebagai kerugian.

* PSAK 102 Paragraf 36

Potongan uang muka akibat pembeli akhir batal membeli barang diakui sebagai kerugian.

\section{b. Penyajian}

1) PSAK 102 Paragraf 37

Piutang murabahah disajikan sebesar nilai neto yang dapat direalisasikan, yaitu saldo piutang murabahah dikurangi penyisihan kerugian piutang.

2) Berdasarkan PSAK 102 Paragraf 38 Marjin murabahah tangguhan disajikan sebagai pengurang (contra account) piutang murabahah.

3) PSAK 102 Paragraf 39

Beban murabahah tangguhan disajikan sebagai pengurang (contra account) utang murabahah. 


\section{c. Pengungkapan}

1). PSAK 102 Paragraf 40

Penjual mengungkapkan hal-hal yang terkait dengan transaksi murabahah, tetapi tidak terbatas pada:

a). Harga perolehan aset murabahah;

b). Janji pemesanan dalam murabahah berdasarkan pesanan sebagai kewajiban atau bukan; dan

c). Pengungkapan yang diperlukan sesuai PSAK 101: Penyajian Laporan Keuangan Syariah.

2). PSAK 102 Paragraf 41

Pembeli mengungkapkan hal-hal yang terkait dengan transaksi murabahah, tetapi tidak terbatas pada:

a). Nilai tunai aset yang diperoleh dari transaksi murabahah;

b). Jangka waktu murabahah tangguh;

c). Pengungkapan yang diperlukan sesuai PSAK 101: Penyajian Laporan Keuangan Syariah.

\section{METODE PENELITIAN}

Penelitian ini adalah jenis penelitian deskriptif, yaitu penelitian yang dilakukan untuk mengetahui nilai variabel mandiri, baik satu variabel atau lebih (independen) tanpa membuat perbandingan, atau menghubungkan dengan variabel yang lain.

Penelitian dilaksanakan pada PT. Bank Sumsel Babel Syariah Cabang Lubuk Linggau, yang beralamat di Jalan Yos Sudarso No. 5-6 Kelurahan Taba Jemekeh Kota Lubuk Linggau Sumatera Selatan.

Penelitian ini menggunakan data primer dan data sekunder. Data primer didapatkan melalui wawancara sedangkan data sekunder, penulis dapatkan melalui dokumen-dokumen yang terkait dengan pembiayaan murabahah pada PT. Bank Sumsel Babel Syariah Cabang Lubuk Linggau.

Dalam penelitian ini penulis menggunakan analisis data kualitatif yang diperoleh melalui berbagai macam teknik pengumpulan data yang kemudian diolah atau dianalisis berdasarkan data yang diperoleh dari PT. Bank Sumsel Babel Syariah Cabang Lubuk Linggau.

Teknik analisis data yang digunakan penulis didalam penelitian ini adalah Teknik analisis yang digunakan adalah analisis deskriptif yaitu analisis data dengan cara memberikan penjelasan dan memberikan predikat kepada variabel yang diteliti sesuai dengan kondisi yang sebenarnya.

\section{HASIL PENELITIAN}

PT. Bank Sumsel Babel Syariah Cabang Lubuklinggau adalah salah satu Lembaga Keuangan keuangan yang melayani dan menjalankan kegiatan operasionalnya berlandaskan prinsip-prinsip syariah. Salah satu bentuk pelayanan dan penerapan prinsip syariah pada PT. Bank Sumsel Babel Syariah Cabang Lubuklinggau adalah melayani kegiatan transaksi jual beli dengan prinsip akad Murabahah. Transaksi jual beli dengan prinsip akad Murabahah pada PT. Bank Sumsel Babel Syariah Cabang Lubuklinggau mengatur tentang pembiayaan Konsumtif. Adapun produk yang termasuk didalam Pembiayaan Konsumtif pada PT. Bank Sumsel Babel Syariah Cabang Lubuklinggau adalah sebagai berikut : 
$>$ Multi jasa iB

Pembiayaan Multijasa iB merupakan fasilitas pembiayaan untuk membiayai keperluan jasa Nasabah seperti pengobatan, pembayaran uang sekolah, pernikahan, dll.

$>$ Griya Sejahtera iB

Pembiayaan Griya Sejahtera iB adalah fasilitas pembiayaan untuk membiayai keperluan Nasabah atas kepemilikan rumah atau bangunan.

$>$ Pemilikan Kendaraan iB

Pemilikan Kendaraan iB adalah fasilitas yang diberikan oleh pihak Bank Sumsel

Babel Syariah kepada Nasabah atas kepemilikan kendaraan.

$>$ Pembelian barang iB

Pembelian Barang iB adalah fasilitas yang diberikan oleh pihak Bank Sumsel Babel Syariah kepada Nasabah atas pembelian barang.

\section{a. Pengakuan dan Pengukuran}

Pengakuan dan pengukuran atas transaksi pembiayaan dengan akad Murabahah pada PT. Bank Sumsel Babel Syariah Cabang Lubuklinggau sebagai berikut:

1) Pengakuan dan pengukuran aset Murabahah

Dalam hal pembelian dan perolehan aset Murabahah, pihak PT. Bank Sumsel Babel Syariah Cabang Kota Lubuklinggau memperoleh aset Murabahah dari pembelian aset murabahah kepada pihak pemasok. Pihak PT. Bank Sumsel Babel Syariah Cabang Lubuklinggau membeli aset murabahah tersebut sesusai dengan pengajuan pesanan yang diperlukan nasabah yang telah disepakati oleh kedua belahpihak yaitu pihak PT. Bank Sumsel Babel Syariah Cabang Lubuklinggau dan calon nasabahnya. Setelah aset Murabahah yang dibeli oleh PT. Bank Sumsel Babel Syariah Cabang Lubuklinggau kepada pemasok tersebut secara sah telah resmi menjadi hak milik PT. Bank Sumsel Babel Syariah Cabang Lubuklinggau, Aset murabahah yang diperoleh oleh PT. Bank Sumsel Babel Syariah Cabang Lubuklinggau dari pembelian kepada pemasok dicatat dan diakui sebagai persediaan sebesar biaya perolehan.

2) Pengakuan dan pengukuran Diskon pembelian aset murabahah

Pada PT. Bank Sumsel Babel Syariah Cabang Lubuklinggau Diskon disebutkan sebagai pengurangan harga dari pemasok yang terjadi baik sebelum ataupun setelah akad. Apabila terdapat diskon pada saat pembelian aset murabahah yang dilakukan oleh PT. Bank Sumsel Babel Syariah Cabang Lubuklinggau dari pihak pemasok, dan diskon atas pembelian aset Murabahah diberikan oleh pemasok sebelum terjadi akad murabahah antara pihak PT. Bank Sumsel Babel Syariah Cabang Lubuklinggau dengan nasabah dilakukan maka diskon pembelian yang diberikan oleh pemasok tersebut diakui sebagai pengurang biaya perolehan aset murabahah oleh pihak PT. Bank Sumsel Babel Syariah Cabang Lubuklinggau. Sedangkan jika diskon atas pembelian aset Murabahah diberikan oleh pemasok kepada pihak bank setelah penandatanganan akad murabahah antara pihak PT. Bank Sumsel Babel Syariah Cabang Lubuklinggau dengan Nasabah dan sesuai akad yang disepakati diskon dari pemasok tersebut menjadi hak pembeli. Adapun oleh pihak PT. Bank Sumsel Babel Syariah Cabang Lubuklinggau diskon pembelian tersebut diakui sebagai Liabilitas kepada pembeli. Adapun perlakuan atas Diskon 
yang diberikan pemasok kepada pihak PT. Bank Sumsel Babel Syariah Cabang Lubuklinggau adalah sebagai berikut.

(a). Jika diskon atas pembelian aset Murabahah diberikan sebelum terjadi akad murabahah, diskon pembelian akan diakui sebagai pengurang biaya perolehan aset murabahah.

(b). Jika diskon atas pembelian aset Murabahah diberikan setelah akad murabahah dan sesuai akad yang disepakati menjadi hak pembeli. Maka diskon pembelian diakui sebagai Liabilitas kepada pembeli.

\section{3) Pengakuan dan pengukuran Piutang Murabahah}

Piutang murabahah pada PT. Bank Sumsel Babel Syariah Cabang Kota Lubuklinggau diukur dan diakui sebesar biaya perolehan aset murabahah ditambah keuntungan yang disepakati. Pada PT. Bank Sumsel Babel Syariah Cabang Kota Lubuklinggau pengukuran ini dilakukan apabila pembiayaan dilakukan $100 \%$ oleh PT. Bank Sumsel Babel Syariah Cabang Kota Lubuklinggau dan nasabah tidak menyerahkan uang muka. Piutang Murabahah pada PT. Bank Sumsel Babel Syariah Cabang Kota Lubuklinggau diperoleh dari akumulasi penjumlahan antara Harga Perolehan Aset dengan Total Margin Murabahah Tangguhan.

\section{4) Pengakuan dan Pengukuran Keuntungan Murabahah}

Keuntungan murabahah pada PT. Bank Sumsel Babel Syariah Cabang Kota Lubuklinggau diperoleh dari penjualan aset murabahah yang disalurkan oleh PT. Bank Sumsel Babel Syariah Cabang Kota Lubuklinggau kepada nasabahnya yang merupakan bagian dari kegiatan penyaluran dan penghimpunan dana PT. Bank Sumsel Babel Syariah Cabang Kota Lubuklinggau. Adapun pengakuan dan pengukuran Keuntungan murabahah pada PT. Bank Sumsel Babel Syariah Cabang Lubuklinggau yaitu sebagai berikut :

$\checkmark$ Keuntungan murabahah dicatat dan diakui kedalam laporan keuangan oleh bank pada saat terjadinya akad Murabahah. Pencatatan ini dilakukan oleh pihak pihak bank jika penjualan aset murabahah kepada nasabahnya dilakukan secara tunai atau secara tangguh yang tidak melebihi satu tahun.

$\checkmark$ Apabila pembiayaan murabahah yang dipesan oleh nasabah secara tangguh lebih dari satu tahun, maka pihak bank mencatat dan mengakui Keuntungan Murabahah secara proporsional yaitu sesuai dengan besaran kas yang berhasil ditagih oleh pihak PT. Bank Sumsel Babel Syariah Cabang Kota Lubuklinggau atas piutang yag dibayarkan nasabahnya. Adapun jurnal yang dicatat oleh pihak PT. Bank Sumsel Babel Syariah Cabang Kota Lubuklinggau adalah sebagai berikut:

\section{5) Pengakuan dan pengukuran Potongan Pelunasan Piutang}

PT. Bank Sumsel Babel Syariah Kota Lubuklinggau memberikan Potongan pelunasan piutang murabahah kepada Nasabah yang melunasi piutang Murabahah tersebut secara tepat waktu atau lebih cepat dari waktu yang disepakati. Adapun potongan pelunasan yang diberikan oleh PT. Bank Sumsel Babel Syariah Kota Lubuklinggau kepada nasabahnya tersebut diakui sebagai pengurang keuntungan murabahah. Potongan Pelunasan Piutang murabahah tersebut berupa potongan margin yang telah ditetapkan sesuai kebijakan yang di ambil oleh pihak PT. Bank Sumsel Babel Syariah Cabang Kota Lubuklinggau. 


\section{6) Pengakuan dan pengukuran Denda}

Untuk tertibnya angsuran pembiayaan, nasabah yang angsurannya dilakukan melalui bendahara gaji dengan pola potong gaji berdasarkan Surat Kuasa Pemotongan Gaji tidak dikenakan sanksi denda keterlambatan angsuran. Namun apabila pembayaran angsurannya tidak dilaksanakan sesuai dengan perjanjian kerjasama yang telah disepakati antara PT Bank Sumsel Babel Syariah Cabang Kota Lubuklinggau dengan Instansi tempat nasabah bekerja, namun selanjutnya akan menjadi penilaian atas kepatuhan/kedisiplinan baik terhadap nasabah maupun terhadap lembaga/instansinya dimasa yang akan datang. Sedangkan terhadap nasabah yang angsuran pembiayaanya dialakukan tidak melalui bendahara gaji maka pihak PT Bank Sumsel Babel Syariah Cabang Kota Lubuklinggau melakukan kebijakan yang dianggap perlu atas agunan yang diberikan nasabah.

Kebijakan yang diterapkan oleh PT. Bank Sumsel Babel Syariah Cabang Kota Lubuklinggau apabila terjadi kelalaian nasabah dalam melunasi utang murabahah yang telah dipesannya telah diatur dan disepakati anatara PT. Bank Sumsel Babel Syariah Cabang Kota Lubuklinggau dan nasabah yang diatur didalam akad pembiayaan dengan prinsip murabahah yang dituangkan dalam pasal 9 yaitu Dalam hal nasabah lalai, menyimpang dari dan/atau membatalkan Akad ini, maka PT Bank Sumsel Babel Syariah Cabang Kota Lubuklinggau berhak mendapat ganti rugi (ta'widh) dari nasabah sebesar kerugian dan/atau biaya yang telah dikeluarkan oleh PT Bank Sumsel Babel Syariah Cabang Kota Lubuklinggau. Kewajiban nasabah yang tidak dilunasi selambat-lambatnya pada saat jatuh tempo pembayaran angsuran atau pelunasan dikenakan denda (ta'zir) yang besarnya sesuai ketentuan yang berlaku pada PT Bank Sumsel Babel Syariah Cabang Kota Lubuklinggau. Dana dari denda (ta'zir) yang diterima PT Bank Sumsel Babel Syariah Cabang Kota Lubuklinggau diperuntukkan sebagai dana sosial sesuai dengan ketentuan yang berlaku pada PT Bank Sumsel Babel Syariah Cabang Kota Lubuklinggau. Denda yang diterima oleh PT Bank Sumsel Babel Syariah Cabang Kota Lubuklinggau atas kelalaian nasabah nya diakui sebagai bagian dana kebajikan.

7) Pengakuan dan pengukuran uang muka

Adapun Pengakuan dan pengukuran uang muka pada PT. Bank Sumsel Babel Syariah Cabang Kota Lubuklinggau tidak diberlakukan. Hal ini dikarenakan seluruh Pembiayaan yang diajukan Nasabah atas Aset Murabahah yang dipesannya ditanggung sepenuh nya oleh PT. Bank Sumsel Babel Syariah Cabang Kota Lubuklinggau sebesar biaya Perolehan Aset Murabahah Tersebut.

\section{b. Penyajian}

Adapun Penyajian atas transaksi pembiayaan dengan akad Murabahah pada PT. Bank Sumsel Babel Syariah Cabang Kota Lubuklinggau sebagai berikut.

1) Penyajian Piutang Murabahah

Dalam kegiatan penjualan Aset Murabahah yang akan dibayar secara tangguh oleh nasabahnya, PT. Bank Sumsel Babel Syariah Cabang Kota Lubuklinggau akan memperoleh Piutang. Piutang tersebut oleh PT. Bank Sumsel Babel Syariah Cabang Kota Lubuklinggau dinamakan Piutang Murabahah. Piutang Murabahah PT. Bank 
Sumsel Babel Syariah Cabang Kota Lubuklinggau disajikan di Neraca pada bagian Aset dengan nama Piutang Murabahah.

\section{2) Penyajian Marjin Murabahah Tangguhan}

Pada PT. Bank Sumsel Babel Syariah Cabang Kota Lubuklinggau Marjin Murabahah Tangguhan diperoleh oleh PT. Bank Sumsel Babel Syariah Cabang Kota Lubuklinggau melalui selisih antara Piutang Murabahah dan Aset Murabahah. Marjin Murabahah Tangguhan pada PT. Bank Sumsel Babel Syariah Cabang Kota Lubuklinggau disajikan di Neraca pada bagian Aset dengan nama Margin Murabahah Tangguhan.

\section{3) Beban murabahah tangguhan}

Pada PT. Bank Sumsel Babel Syariah Cabang Lubuklinggau tidak mencatat adanya beban Murabahah tangguhan. Hal ini dikarenakan terkait penurunan nilai aset Aset Murabahah yang dijual oleh pihak PT. Bank Sumsel Babel Syariah Cabang Lubuklinggau kepada Nasabahnya telah sepenuhnya menjadi kewajiban Pembeli.

\section{c. Pengungkapan}

PT. Bank Sumsel Babel Syariah Cabang Lubuklinggau dalam kegiatan transaksi penjualan Aset murabahah kepada nasabahnya bertindak sealaku penjual. Sedangkan Nasabah yang memperoleh aset murabahah melalui pembelian secara tunai ataupun tangguh dari PT. Bank Sumsel Babel Syariah Cabang Lubuklinggau bertindak sebagai pembeli. PT. Bank Sumsel Babel Syariah Cabang Lubuklinggau selaku penjual mengungkapkan hal-hal yang dianggap perlu terkait aset murabahah yang akan diterima oleh nasabahnya.

PT. Bank Sumsel Babel Syariah Cabang Lubuklinggau mengungkapkan harga perolehan Aset Murabahah yang diperoleh oleh PT. Bank Sumsel Babel Syariah Cabang Lubuklinggau dari pihak pemasok. Kemudian PT. Bank Sumsel Babel Syariah Cabang Lubuklinggau akan menjual aset murabahah tersebut kepada nasabah dengan nilai yang lebih tinggi dari nilai perolehan aset yang diperoleh oleh PT. Bank Sumsel Babel Syariah Cabang Kota Lubuklinggau dari pihak pemasok tersebut sesuai dengan kebijakan yang telah ditetapkan oleh PT. Bank Sumsel Babel Syariah Cabang Kota Lubuklinggau. Kemudian PT. Bank Sumsel Babel Syariah Cabang Kota Lubuklinggau akan mengungkapkan bahwa Aset murabahah akan menjadi hak milik nasabah secara sah setelah nasabah telah melunasi seluruh kewajiban nasabah atas aset tersebut.

\section{E. PEMBAHASAN}

Analisis penulis mengenai Perlakuan akuntansi atas pembiayaan Murabahah yang ada pada PT. Bank Sumsel Babel Syariah Cabang Lubuklinggau dapat diuraikan sebagai berikut:.

\section{a. Pengakuan dan Pengukuran}

1. Aset murabahah yang diperoleh oleh PT. Bank Sumsel Babel Syariah Cabang Kota Lubuklinggau dari pembelian kepada pihak pemasok yang kemudian dijual kembali kepada nasabah dicatat dan diakui sebagai persediaan sebesar biaya perolehan. Berdasarkan Psak 102 paragraf 18 disebutkan bahwa pada saat 
perolehan aset murabahah diakui sebagai persediaan sebesar biaya perolehan. Adapun Pencatatan yang dilakukan PT Bank Sumsel Babel Syariah Cabang Lubuklinggau atas aset murabahah yang diperoleh telah sesuai berdasarkkan PSAK 102.

2. Pada prinsipnya PT. Bank Sumsel Babel Syariah Cabang Kota Lubuklinggau memberikan diskon kepada nasabahnya berdasarkan diskon yang diberikan oleh pihak pemasok kepada PT. Bank Sumsel Babel Syariah Cabang Lubuklinggau atas pembelian aset murabahah. PT. Bank Sumsel Babel Syariah Cabang Lubuklinggau memberikan diskon kepada nasabahnya apabila diskon yang diberikan oleh pemasok terjadi sebelum akad murabahah antara pihak PT. Bank Sumsel Babel Syariah Cabang Kota Lubuklinggau dengan nasabah. Diskon pembelian yang diberikan oleh pemasok tersebut diakui sebagai pengurang biaya perolehan aset murabahah. Sedangkan jika diskon atas pembelian aset Murabahah diberikan oleh pemasok kepada pihak PT. Bank Sumsel Babel Syariah Cabang Lubuklinggau setelah penandatanganan akad Murabahah antara pihak PT. Bank Sumsel Babel Syariah Cabang Lubuklinggau dengan Nasabah dan sesuai akad yang disepakati diskon dari pemasok tersebut diakui sebagai hak pembeli. Sedangkan Pengakuan dan pengukuran berdasarkan PSAK 102 Diskon pembelian aset murabahah diakui sebagai: pengurang biaya perolehan aset murabahah, jika terjadi sebelum akad murabahah. Liabilitas kepada pembeli, jika terjadi setelah akad murabahah dan sesuai akad yang disepakati menjadi hak pembeli. Pencatatan yang dilakukan PT Bank Sumsel Babel Syariah Cabang Lubuklinggau atas aset murabahah telah sesuai berdasarkkan PSAK 102

3. Pada PT. Bank Sumsel Babel Syariah Cabang Lubuklinggau Piutang murabahah dicatat sebesar harga jual yaitu harga pokok ditambah dengan margin/keuntungan. Margin ditangguhkan merupakan selisih antara harga jual dengan harga pokok. Margin keuntungan yang diperoleh PT Bank Sumsel Babel Syariah Cabang Lubuklinggau sesuai dengan kesepakatan yang telah disetujui oleh PT Bank Sumsel Babel Syariah Cabang Lubuklinggau dan nasabahnya. Perlakuan dan pengukuran Piutang murabahah berdasarkan PSAK 102 Pada saat akad murabahah, piutang murabahah diakui sebesar nilai perolehan ditambah keuntungan yang disepakati. Pencatatan yang dilakukan PT Bank Sumsel Babel Syariah Cabang Lubuklinggau dalam piutang murabahah telah sesuai dengan PSAK 102

4. Didalam menjual dan menyalurkan aset murabahah kepada nasabahnya, PT. Bank Sumsel Babel Syariah Cabang Lubuklinggau melakukan penjualan secara tunai dan secara tangguh. Keuntungan murabahah dicatat sebesar nilai bersih yang diperoleh atas penjualan aset tersebut. Penjualan digolongkan secara tunai pada PT. Bank Sumsel Babel Syariah Cabang Lubuklinggau apabila penjualan aset murabahah tersebut dijual secara tangguh kurang dari satu tahun. Apabila pembiayaan murabahah yang dipesan oleh nasabah secara tangguh lebih dari satu tahun, maka pihak PT. Bank Sumsel Babel Syariah Cabang Lubuklinggau mencatat dan mengakui Keuntungan Murabahah secara proporsional yaitu sesuai dengan besaran kas yang berhasil ditagih oleh pihak PT. Bank Sumsel Babel Syariah Cabang Lubuklinggau atas piutang yag dibayarkan nasabahnya. Perlakuan dan pengukuran berdasarkan PSAK 102 Keuntungan murabahah diakui: 
pada saat terjadinya penyerahan barang jika dilakukan secara tunai atau secara tangguh yang tidak melebihi satu tahun.

> Selama periode akad sesuai dengan tingkat risiko dan upaya untuk merealisasikan keuntungan tersebut untuk transaksi tangguh lebih dari satu tahun. Pencatatan yang dilakukan PT Bank Sumsel Babel Syariah Cabang Lubuklinggau dalam piutang murabahah telah sesuai dengan PSAK 102.

5. PT Bank Sumsel Babel Syariah Cabang Lubuklinggau memberikan potongan pelunasan piutang murabahah kepada nasabah yang melunasi lebih cepat dari waktu yang telah disepakati. Potongan pelunasan piutang Murabahah yang diberikan bank kepada nasabahnya tersebut diakui sebagai pengurangan margin murabahah. Perlakuan dan pengukuran Potongan pelunasan piutang Murabahah berdasarkan PSAK 102 yaitu Potongan pelunasan piutang murabahah yang diberikan kepada pembeli yang melunasi tepat waktu atau lebih cepat dari waktu yang telah disepakati diakui sebagai pengurangan keuntungan murabahah. Pencatatan yang dilakukan PT Bank Sumsel Babel Syariah Cabang Kota Lubuklinggau atas Potongan pelunasan piutang Murabahah telah sesuai dengan PSAK 102.

6. Denda yang diterima PT Bank Sumsel Babel Syariah Cabang Lubuklinggau diperuntukkan sebagai dana sosial sesuai dengan ketentuan yang berlaku pada bank. Denda yang diterima oleh PT Bank Sumsel Babel Syariah Cabang Kota Lubuklinggau atas kelalaian nasabah nya diakui sebagai bagian dana kebajikan. Perlakuan dan pengukuran Denda berdasarkan PSAK 102 yaitu Denda dikenakan jika pembeli lalai dalam melakukan kewajibannya sesuai dengan akad, dan denda yang diterima diakui sebagai bagian dana kebajikan. Pencatatan yang dilakukan PT Bank Sumsel Babel Syariahcabang Lubuklinggau atas Denda telah sesuai dengan PSAK 102

7. PT. Bank Sumsel Babel Syariah Cabang Kota Lubuklinggau tidak menerima uang muka, karena penjualan aset murabahah oleh PT. Bank Sumsel Babel Syariah Cabang Kota Lubuklinggau yang dibeli kepada pemasok dibeli secara tunai oleh bank yang kemudian dijual kembali kepada nasabhnya. PT. Bank Sumsel Babel Syariah Cabang Kota Lubuklinggau juga dapat mewakilkan secara langsung pembelian aset murabahah oleh nasabahnya. Dalam hal ini PT Bank Sumsel Babel Syariah Cabang Kota Lubuklinggau mewakilkan pembelian barang kepada nasabahnya. Dengan syarat nasabah memberikan bukti pembelian. Sedangkan Pengakuan dan pengukuran uang muka berdasarkan PSAK 102 yaitu uang muka diakui sebagai pembayaran piutang (merupakan bagian pokok). Jika barang batal dibeli oleh pembeli, maka uang muka dikembalikan kepada pembeli setelah diperhitungkan dengan biaya-biaya yang telah dikeluarkan penjual. Pencatatan yang dilakukan oleh PT. Bank Sumsel Babel Syariah Cabang Kota Lubuklinggau atas Uang muka kurang sesuai berdasarkan PSAK 102 paragraf 36, tetapi tidak mengurangi kinerja PT. Bank Sumsel Babel Syariah Cabang Kota Lubuklinggau dalam memberikan pelayanan jual beli sesuai dengan prinsip-prinsip Syariah yang ditetapkan.

\section{b. Penyajian}

1. Piutang Murabahah

Piutang Murabahah pada PT Bank Sumsel Babel Syariah Cabang Lubuklinggau disajikan sebesar jumlah bersih dari seluruh pembiayaan murabahah (piutang). Penyajian berdasarkan PSAK 102 paragraf 37 yaitu 
Piutang murabahah disajikan sebesar nilai yang dapat direalisasikan yaitu saldo piutang murabahah dikurangi penyisihan kerugian piutang. Margin murabahah tangguhan disajikan sebagai pengurang piutang. Pencatatan yang dilakukan PT Bank Sumsel Babel Syariah Cabang Lubuklinggau telah sesuai dengan PSAK 102.

2. Margin Murabahah Tangguhan

Marjin Murabahah Tangguhan pada PT. Bank Sumsel Babel Syariah Cabang Lubuklinggau disajikan di Neraca pada bagian Aset dengan nama Margin Murabahah Tangguhan. Margin Murabahah Tangguhan pada PT. Bank Sumsel Babel Syariah Cabang Lubuklinggau disajikan sebagai pengurang piutang murabahah. Penyajian yang dilakukan oleh PT. Bank Sumsel Babel Syariah Cabang Lubuklinggau atas akun Margin Murabahah Tangguhan telah sesuai dengan PSAK 102 paragraf 38 tentang Margin Murabahah Tangguhan yang disebutkan bahwa Margin Murabahah Tangguhan disajikan sebagai pengurang (Contra Account) piutang murabahah.

\section{c. Pengungkapan}

Kebijakan akuntansi yang ada di PT Bank Sumsel Babel Syariah Cabang Kota Lubuklinggau juga mengungkapkan tentang transaksi-transaksi murabahah seperti perolehan aset murabahah, persediaan piutang murabahah, margin murabahah dan sebagainya. Pengungkapan berdasarakan PSAK 102 yaitu Penjual mengungkapkan hal-hal yang terkait dengan transaksi murabahah, tetapi tidak terbatas pada harga perolehan aset murabahah, janji pemesanan dalam murabahah berdasarkan pesanan sebagai kewajiban atau bukan pengungkapan yang diperlukan sesuai PSAK 101 tentang penyajian laporan keuangan syariah. Adapun Pengungkapan yang dilakukan oleh PT Bank Sumsel Babel Syariah Cabang Kota Lubuklinggau telah sesuai dengan PSAK 102 paragraf 40 dan paragraf 41 tentang pengungkapan yang perlu dilakukan oleh pihak penjual dalam transaksi pembiayaan Murabahah.

\section{F. KESIMPULAN DAN SARAN}

Berdasarkan hasil penelitian Analisis perlakuan akuntansi atas pembiayaan Murabahah pada PT Bank Sumsel Babel Syariah Cabang Kota Lubuklinggau dapat disimpulkan bahwa perlakuan akuntansi atas pembiayaan Murabahah pada PT Bank Sumsel Babel Syariah Cabang Kota Lubuklinggau dalam hal pengakuan, pengukuran, penyajian serta pengungkapan atas Pembiayaan Murabahah telah sesuai dengan PSAK 102. Hanya saja terdapat perbedaan dalam hal penerapan, hal ini disebabkan oleh adanya kebijakan yang memang perlu diambil oleh PT. Bank Sumsel Babel Syariah Cabang Kota Lubuklinggau.

Dalam hal pengakuan dan pengukuran hendaknya PT Bank Sumsel Babel Syariah Cabang Kota Lubuklinggau menerima apabila ada nasabah yang ingin memberikan uang muka. Hal ini dikarenakan adanya perbedaan kemampuan nasabah dalam membayar utang yang diperoleh serta pengakuan tentang uang muka juga diatur didalam PSAK 102 yang berbasis syariah. 


\section{DAFTAR PUSTAKA}

Arikunto, Suharsimi. 2010. Prosedur Penelitian Suatu Pendekatan Praktik. Jakarta: Rineka Cipta

Irfan. 2018. Analisis Perakuan Akuntansi Pembiayaan Murabahah Berdasarkan PSAK 102 pada PT. Bank Syariah Mandiri Cabang Makasar. Jurnal Penelitian.

Kautsar Riza Salman. 2017. Akuntansi Perbankan Syariah: Berbasis PSAK Syariah. Jakarta. Permata Puri Media.

Nur Aini. 2011. Analisis Pembiayaan Dengan Prinsip Murabahah dan Perlakuan Akuntansinya pada PT. Bank Riau Syariah Pekan Baru. Jurnal Penelitian.

Rizal Yaya, dkk. 2012. Akuntansi Perbankan syariah. Jakarta: Salemba Empat.

Saleh Muhammad dan Ikit. 2014. Pengantar Bnak Syariah. Lubuklinggau: Pustaka Al-Azhar.

Sugiyono.2017. Metode Penelitian dan Pengembangan (Research and Development $/ R \& D)$. Bandung: Alfabeta.

Umam Khotibul dan Utomo Setiawan Budi. 2016. Perbankan Syariah. Jakarta: PT. Raja Grafindo Persada.

Zulia Hanum. 2014. Analisis Penerapan Transaksi Murabahah pada PT. Bank Pembiayaan Rakyat (BPR) Syariah Gebu Prima Medan. Jurnal Penelitian. 